\title{
AGE AND GROWTH OF SPAWNING LONGNOSE GAR (LEPISOSTEUS OSSEUS) IN A NORTH CENTRAL TEXAS RESERVOIR
}

\author{
Samuel W. Kelley ${ }^{1}$
}

\begin{abstract}
The longnose gar (Lepisosteus osseus) is a primitive predaceous fish common throughout much of the east central United States, but research on its age and growth in lacustrine systems is rare. To characterize gar age and growth, I used bowfishing to collect spawning longnose gar in spring 2010 from littoral zones at Lake Arrowhead, Clay County, Texas. Females were older than males but significantly exceeded males in total length and mass when age was controlled. Von Bertalanffy growth curves suggested that males had faster growth rates, smaller maximum lengths, and shorter life spans than did females. However, females were always longer than males at any given age. Bowfishing capture beyond distances of $9 \mathrm{~m}$ was biased toward larger fish, but the method was viable for collecting spawning longnose gar at close range. This study will assist fisheries managers and aquaculturists by providing growth-age relationships for longnose gar in a southern lacustrine system.
\end{abstract}

RESUMEN.-El pejelagarto narigudo (Lepisosteus osseus) es un pez depredador primitivo que es común a lo largo de una gran parte del centro-este de los Estados Unidos; sin embargo, la investigación sobre su edad y crecimiento en sistemas lacustres es rara. En la primavera de 2010, utilicé pesca con arco y flecha para colectar pejelagartos narigudos en estado de desove de las zonas litorales del Lago Arrowhead, condado de Clay, Texas para caracterizar sus edades y crecimiento. Las hembras fueron mayores en edad que los machos, pero al corregir por la edad, éstas superaban considerablemente a los machos en el largo y la masa total. Las curvas de crecimiento de Von Bertalanffy indicaron que los machos tuvieron tasas de crecimiento más aceleradas, una longitud máxima menor y un promedio de vida más corto que las hembras. Sin embargo, las hembras a cualquier edad siempre superaron en longitud a los machos. La captura con arco y flecha de más allá de 9 metros se orientó hacia los peces más grandes, pero el método demostró ser viable para la captura del pejelagarto narigudo en estado de desove a distancias cercanas. Este estudio ayudará a los encargados de pesquerías y acuicultura porque describe las relaciones entre el crecimiento y la edad del pejelagarto narigudo en un sistema lacustre del sur.

The longnose gar (Lepisosteus osseus) is a primitive predaceous fish that is abundant throughout much of the east central United States. It may exceed lengths of $1.8 \mathrm{~m}$, it approaches $23 \mathrm{~kg}$ in weight, and, among gar species in the United States, it is surpassed in size only by the alligator gar (Atractosteus spatula). Unlike the alligator gar, the longnose gar currently has a secure status; however, effective management and conservation strategies require more biological data from lacustrine and riverine systems across its range. Furthermore, lepisosteids have been recognized as important environmental indicators and biomarker species (Hartley et al. 1996, Huang et al. 1997, Huggett et al. 2001, Watanabe et al. 2003, Burger et al. 2004).

Previous studies have provided insight on the growth and age of longnose gar in riverine systems in the central United States. Comparative data from lacustrine systems (Klaassen and
Morgan 1974), however, are lacking, particularly in the southern portion of the gar's range. While electrofishing is widely used to capture many fish species, including longnose gar (Sutton et al. 2009), it has produced poor results for lepisosteids from Lake Arrowhead (Howell and Mauk 2004, 2008). The tendency of stunned gar to sink rather than float up for visible dip net captures (Burr 1931) may bias catch rates. High conductivity, turbidity, and depths $>1.2 \mathrm{~m}$ (frequent characteristics in southern reservoirs) also reduce electrofishing efficiency. Additionally, most previous studies used passive capture techniques (e.g., gill nets or trap boxes; Klaassen and Morgan 1974, Johnson and Noltie 1996, Robertson et al. 2008) or a combination of passive and active capture techniques (e.g., gill nets, dip nets, trotlines, seining, and electrofishing; Netsch and Witt 1962, Tyler et al. 1994, Johnson and Noltie 1997) to obtain specimens.

${ }^{1}$ U.S. Geological Survey, 3010 Buchanan St., Wichita Falls, TX 76308. E-mail: skelley@usgs.gov 


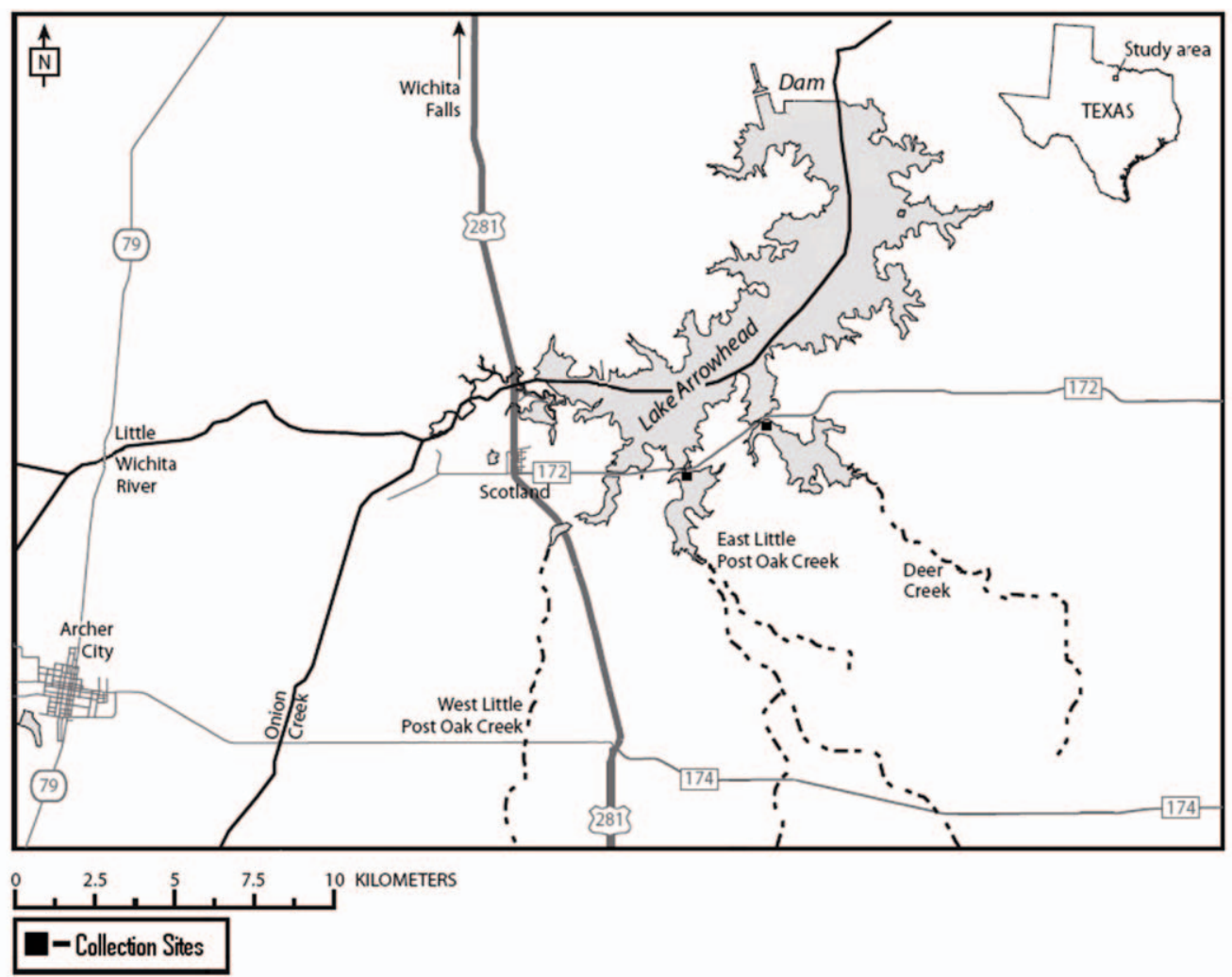

Fig. 1. Lake Arrowhead study site, Clay County, Texas. Black squares near the East Little Post Oak Creek and Deer Creek bridges indicate collection sites.

Because spawning longnose gar often congregate near the surface in littoral shallows, I predicted that bowfishing would be a viable collection method. Additionally, I desired to characterize age and growth of longnose gar from a southern reservoir system to provide a comparison to previous studies from the central United States. I hypothesized that female longnose gar would be generally larger and older than male longnose gar, as illustrated by previous studies. Moreover, I expected that both male and female longnose gar from a southern reservoir would grow faster than riverine congeners farther north due to the longer growing season and higher productivity of lacustrine systems (Johnson and Noltie 1997).

\section{METHODS}

Longnose gar were collected 23-26 April and 29 May 2010 from Lake Arrowhead, a reservoir impounded in 1966 by damming the Little Wichita River in Clay County, Texas.
The lake has a surface area of 6036 ha, a maximum depth of $14 \mathrm{~m}$ near the dam, and high turbidity. The lake elevation fluctuates from about 1.2 to $1.8 \mathrm{~m}$ due to extensive municipal water use by the city of Wichita Falls and neighboring communities.

I collected longnose gar using archery (bowfishing) equipment and methods compliant with regulations of the Texas Parks and Wildlife Department. Specifically, I took all available shots at gar in range (distances $\leq 14 \mathrm{~m}$ ), while I walked along the shoreline at 2 sites in the lower region of the reservoir (near Deer Creek bridge and near East Little Post Oak Creek bridge; Fig. 1). The collected specimens were assumed to be a random sample of the adult spawning population.

Collected gar specimens were placed on ice and examined within 24 hours of capture. Total length (TL, mm) and mass $(\mathrm{g})$ were recorded for each specimen. Sex was determined following the methods of Ferrara and Irwin (2001), although sex was readily apparent from the 
presence of eggs or milt during internal examination. Age was determined by counting annuli on the largest left branchiostegal ray of each fish (Netsch and Witt 1962). The rays were removed, boiled briefly in water (Johnson and Noltie 1997), cleaned in a dilute bleach solution (Klaassen and Morgan 1974), and cleared in mineral oil. Annuli bands that extended completely across the ray were counted using a dissecting microscope (Johnson and Noltie 1997, Love 2004). Because of false annuli bands, a few gar specimen ages were tentative. In those cases, a second observer also counted annuli, and counts were discussed until an agreement on age was reached. A Wild Heerbrugg microscope with an ocular micrometer was used to obtain all branchiostegal ray measurements, including those between each annulus for back-calculation of TL by age.

Back-calculated TL (BCTL) was determined following the methods and equations described by Johnson and Noltie (1997 and references therein) and later slightly modified by Love (2004):

$\log \mathrm{TL}_{\mathrm{b}}=\mathrm{a}+\left(\log \mathrm{TL}_{\mathrm{c}}-\mathrm{a}\right)\left(\log \mathrm{BA}_{\mathrm{a}} / \log \mathrm{BL}_{\mathrm{t}}\right)$,

where $\mathrm{TL}_{\mathrm{b}}$ is the back-calculated TL at age $\mathrm{b}$, $\mathrm{TL}_{\mathrm{c}}$ is the TL of the fish at capture, $\mathrm{BA}_{\mathrm{a}}$ is the branchiostegal ray length from the base to the median point on the annulus, and $\mathrm{BL}_{\mathrm{t}}$ is the total branchiostegal ray length from base to tip. The constant (a) used in the above equation was obtained from the regression (all specimens) of TL at capture on the total length of the branchiostegal ray (BL):

$$
\log \mathrm{TL}=\mathrm{a}+\mathrm{b} \log \mathrm{BL} .
$$

BCTLs yielded far greater numbers of age estimates than did lengths at age of capture alone, providing total length estimates from each year of life for every captured fish. Mean BCTLs were plotted by year for both sexes from age one to the oldest age of capture. Logtransformed BCTLs were regressed separately by sex on log-transformed age for comparison to previous studies.

Age, mass, and TL at capture of male and female gar were compared using 2-tailed equalvariance $t$ tests, following Shapiro-Wilk normality tests and modified Levene tests to check for equal variance. Male and female mass were $\log _{10}$-transformed prior to testing in order to normalize female mass. The length-to-mass relationship of both sexes combined was determined by linear regression using $\log _{10}$-transformed age and mass values.

Initial results demonstrated that age, mass, TL at capture, and BCTLs of female gar were significantly greater than those for males. However, age was suspected to exert a substantial influence on these metrics; thus, statistical comparisons were made between sexes using a general linear model ANCOVA (Johnson and Noltie 1997, Love 2004) with age and $\log _{10}$ age as covariates, TL and $\log _{10}$ BCTL as response variables, and sex as a factor variable. Before conducting this test, sex-by-age interactions and assumptions of parallel slopes were tested with preliminary analyses using multiple regression and ANOVA (dependent variables $[\mathrm{Y}]=\mathrm{TL}$ and $\log _{10}$ BCTL; numerical independent variables $[\mathrm{X}]=$ age and $\log _{10}$ age; categorical independent variable $[\mathrm{X}]=\operatorname{sex}$ ) to confirm that differences between sexes among mean TLs and BCTLs were not dependent on age alone.

Linear methods in fish growth calculations have fallen out of favor with many researchers; however, only Sutton et al. (2009) have published a growth curve for longnose gar using nonlinear methods, although Ferrara (2001) and McGrath (2010) made noteworthy contributions using nonlinear methods as well. Thus, for comparative purposes, I derived growth estimate curves (by sex) from plotted BCTLs by age using the von Bertalanffy (1938) growth model:

$$
l_{t}=L_{\infty}\left(1-\mathrm{e}^{-K\left(t-t_{0}\right)}\right),
$$

where $l_{t}$ is length at age $t, L_{\infty}$ is the asymptotic length, $K$ is the growth-rate parameter, and $t_{0}$ is a theoretical age (usually a negative number) at which the total length is presumed equal to zero.

All statistical tests were carried out using NCSS 2007 (NCSS, J. Hintze, Kaysville, UT). Regression and von Bertalanffy (VB) plots were created using the regression wizard and dynamic fit wizard in SigmaPlot ${ }^{\circledR} 10.0$ (Systat, San Jose, $\mathrm{CA})$. Results were considered statistically significant at $P<0.05$.

\section{RESUlTS}

Twenty-four longnose gar (13 ô ô, 11 우 우) were collected via bowfishing (Fig. 1). Collection efforts were hampered by highly turbid 
waters from recent rainfall, short-lived spawning activities, and poor surface visibility due to high winds. Visual observations suggested a male bias in the sex ratio of spawning longnose gar, and it was not unusual to observe 2-6 males corralling a single large female towards shoreline rocks in competitive efforts to fertilize her eggs. Additionally, females rarely released all of their eggs at once but rather in multiple locations near the shoreline, often allowing additional males opportunities for fertilization.

Bowfishing proved to be most effective at shot distances of about $9 \mathrm{~m}$ or less. Distances $>9 \mathrm{~m}$ were biased toward successful captures of larger specimens and against captures of smaller specimens, as only a few females (i.e., larger targets) were hit beyond $9 \mathrm{~m}$. In this study, most shots were taken within $9 \mathrm{~m}$ of the collector because of the longnose gars' affinity for spawning along shoreline rocks.

Sexual Dimorphism in Age, Mass, and TL

Mean age $( \pm S D)$ of captured female longnose gar, as determined by branchiostegal ray annuli counts, significantly exceeded that of captured males $(q+q=16.2 \pm 4.1$ years, ô $\hat{o}=$ $9 \pm 2.9$ years; $t=5.03, \mathrm{df}=22, P<0.0001$ ). Females also had significantly greater mean $( \pm \mathrm{SD}) \operatorname{mass}(q q=6878 \pm 2760 \mathrm{~g}$, ๙ิ $\hat{\sigma}=$ $2066 \pm 584 \mathrm{~g} ; t=9.20, \mathrm{df}=22, P<0.0001)$

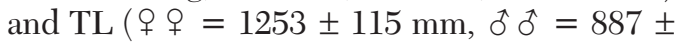
$68 \mathrm{~mm} ; t=9.65$, df $=22, P<0.0001)$ than males; however, the influence of age on these results was suspect, requiring further ANCOVA analyses. Age was a significant covariate on mass $(F=29.12$, df $=1, P<0.0001)$; nevertheless, females significantly outweighed males when the model was controlled for age $(F=$ 33.61, df $=1, P<0.0001)$. The assumption that the slopes of TL at capture to age were equal between males and females was not rejected $(F=0.085$, df $=1, P=0.774)$, and influence of age (covariate) on TL was significant $(F=31.02$, df $=1, P<0.0001)$; however, captured females had significantly greater mean TLs than captured males when controlled for age $(F=36.70$, df $=1, P<0.0001)$.

Despite dimorphism in mass, combined male and female TLs proved a good predictor of mass for both sexes, explaining the majority of variation $\left(r^{2}=0.983\right)$ in a linear relationship (Fig. 2A). Additionally, branchiostegal ray length was a good predictor of TL for longnose gar $\left(r^{2}=\right.$
0.896; Fig. 2B), thus supporting use of the slope value as a constant for deriving BCTLs.

\section{Back-Calculated TL vs. Age}

The assumption that the slopes of the BCTLversus-age relationship were equal between males and females was not rejected $(F=1.938$, $\mathrm{df}=1, P=0.165)$, and influence of age (covariate) on BCTL was significant $(F=1180.4, \mathrm{df}=1$, $P<0.0001$ ), validating the ANCOVA; however, mean BCTLs between sexes differed significantly when controlled for age $(F=567.46$, df $=1, P<0.0001)$, with females exhibiting significantly longer BCTLs than males (Fig. 3).

\section{Growth}

Log-transformed regressions of growth provided good fits for male and female longnose gar from Lake Arrowhead (Fig. 3A). The VB growth curves were also a good fit for longnose gar in this study; although, as in the regression analyses, they explained more of the variation for males than for females. Mean male TLs did not exceed those of females at same-age comparisons. In addition, VB growth parameter values were larger for males $(K=0.35)$ than for females $(K=0.18)$, although females had greater asymptotic lengths $\left(L_{\infty}=1307\right)$ than males $\left(L_{\infty}=923\right.$; Fig. 3B $)$.

\section{Discussion}

Bowfishing methods have seen little use in scientific study but may provide insights into fish populations that are not easy to obtain using traditional methods, especially for large fish in older age classes. Quinn (2010) lists 89\%-100\% of bowfishing captures in Arkansas as exceeding published size-at-maturity estimates for multiple species, including longnose gar, and this study supports his findings. Bowfishing success depends largely upon location, season, and weather conditions (Quinn 2010), as well as skill of the collector, but this is true for all collection methods.

Longnose gar in this study were most similar in age to those described by Netsch and Witt (1962) and were notably older than lacustrine gar from Kansas (Klaassen and Morgan 1974). Mean BCTLs for male gar from Lake Arrowhead were slightly larger than those reported in previous studies for ages 2-10 but were similar to, or smaller than, mean BCTLs for riverine gar from Missouri at ages 1 and 

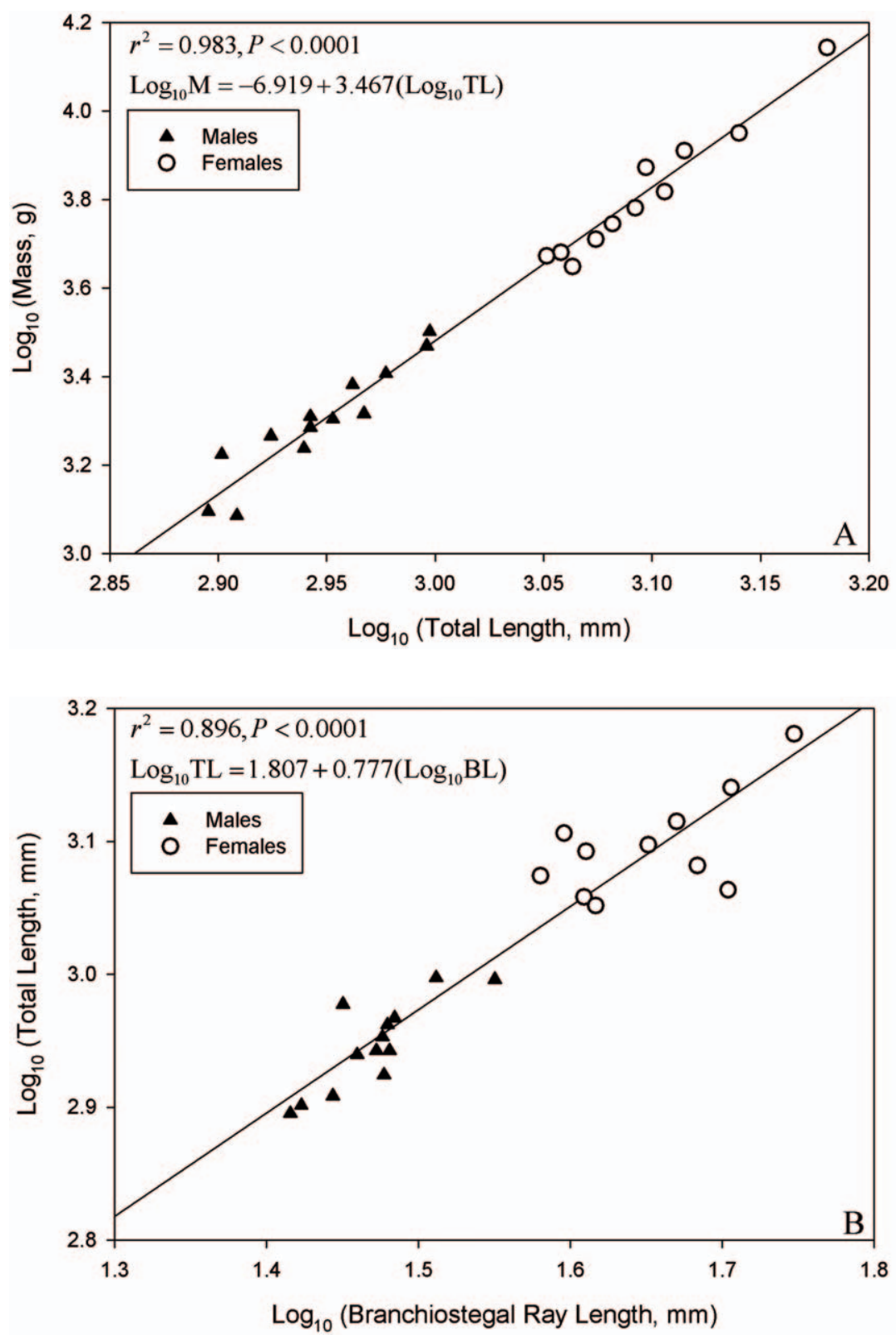

Fig. 2. Attribute relationships for combined adult male (filled triangles; $n=13$ ) and female (open circles; $n=11$ ) spawning longnose gar (Lepisosteus osseus) collected from Lake Arrowhead, Clay County, Texas, April-May 2010: A, mass (M) versus total length (TL); B, total length (TL) versus branchiostegal ray length (BL).

11-14 (Fig. 4A). Mean BCTLs for female longnose gar from Lake Arrowhead exceeded those of riverine gar from Missouri (Netsch and Witt 1962, Johnson and Noltie 1997) and reservoir gar from Kansas (Klaassen and Morgan 1974) at all ages, though some overlap was apparent (Fig. 4B).
Growth of young $(<1$-year-old) longnose gar is very rapid and does not conform well to the VB growth curve, as evidenced by poorer fit results with trial inputs provided by Echelle and Riggs (1972) of TLs equaling $10 \mathrm{~mm}$ at hatch and $20 \mathrm{~mm}$ at 10 days. The VB growth curve for Lake Arrowhead female longnose gar 

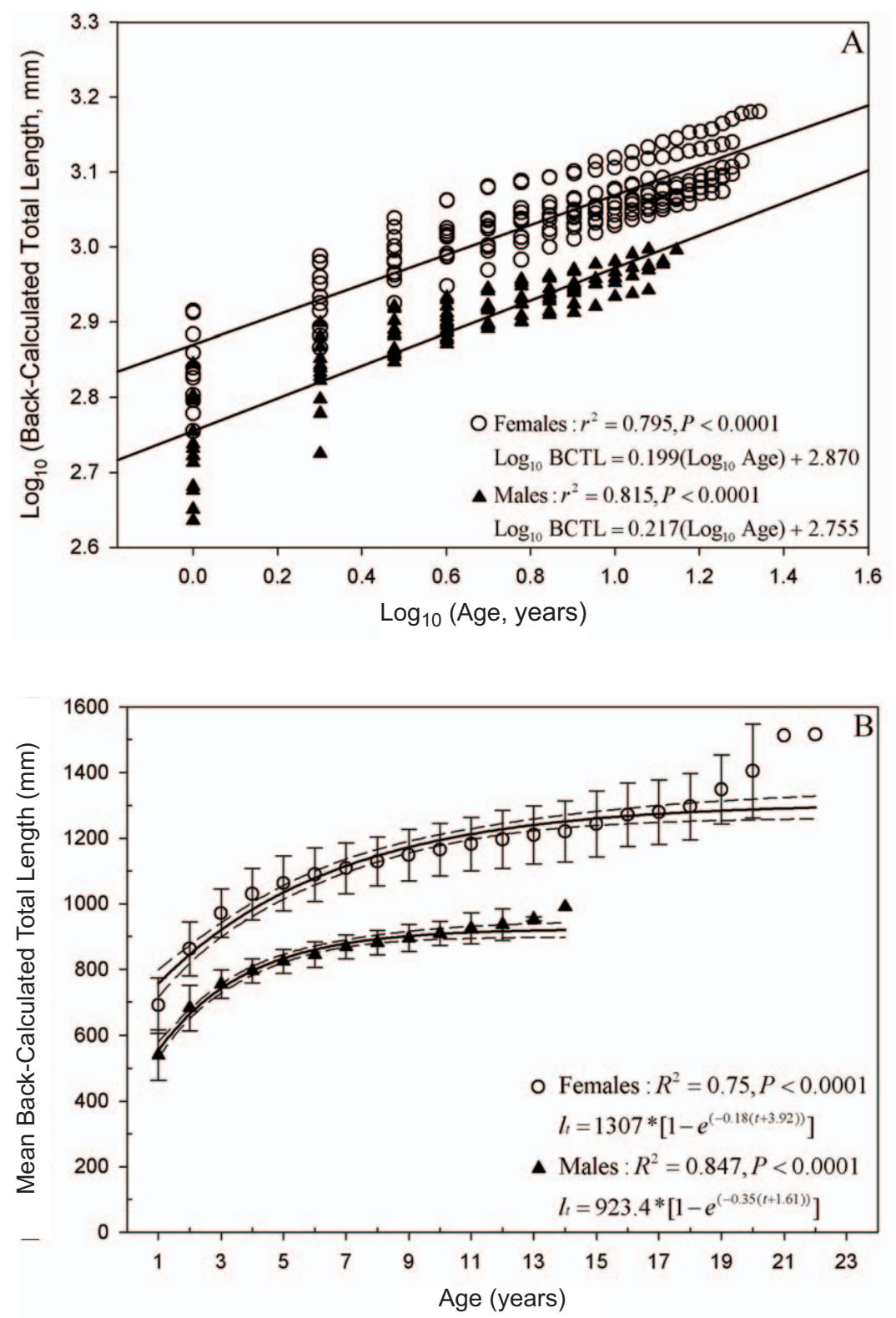

Fig. 3. Length versus age relationships based on branchiostegal ray annuli counts $(n=117)$ for male (filled triangles; $n=13$ ) and counts $(n=178)$ for female (open circles; $n=11$ ) spawning longnose gar (Lepisosteus osseus) collected from Lake Arrowhead, Clay County, Texas, April-May 2010: A, $\log _{10}$-transformed back-calculated total length versus $\log _{10^{-}}$ transformed age; B, mean $( \pm S D$ ) back-calculated total length versus age plots plus von Bertalanffy growth curves (dotted lines $=95 \%$ confidence intervals). Data points lacking \pm SD error bars indicate singular specimens at those age classes.

appeared to slightly overestimate TL at age 1 , and underestimate TL at ages $>19$ years (Fig. 3B). Although increased sample size might ameliorate some of these disparities, results from this study and from Netsch and Witt (1962) suggest that large, old female gar have variable
TLs and diverge from the standard asymptotic VB growth curve. Larger gar tend to prey upon larger forage species (Tyler et al. 1994) and may exhibit a bimodal growth pattern as a result of diet shifts to larger prey. Overall, VB growth parameter values suggested that males in Lake 

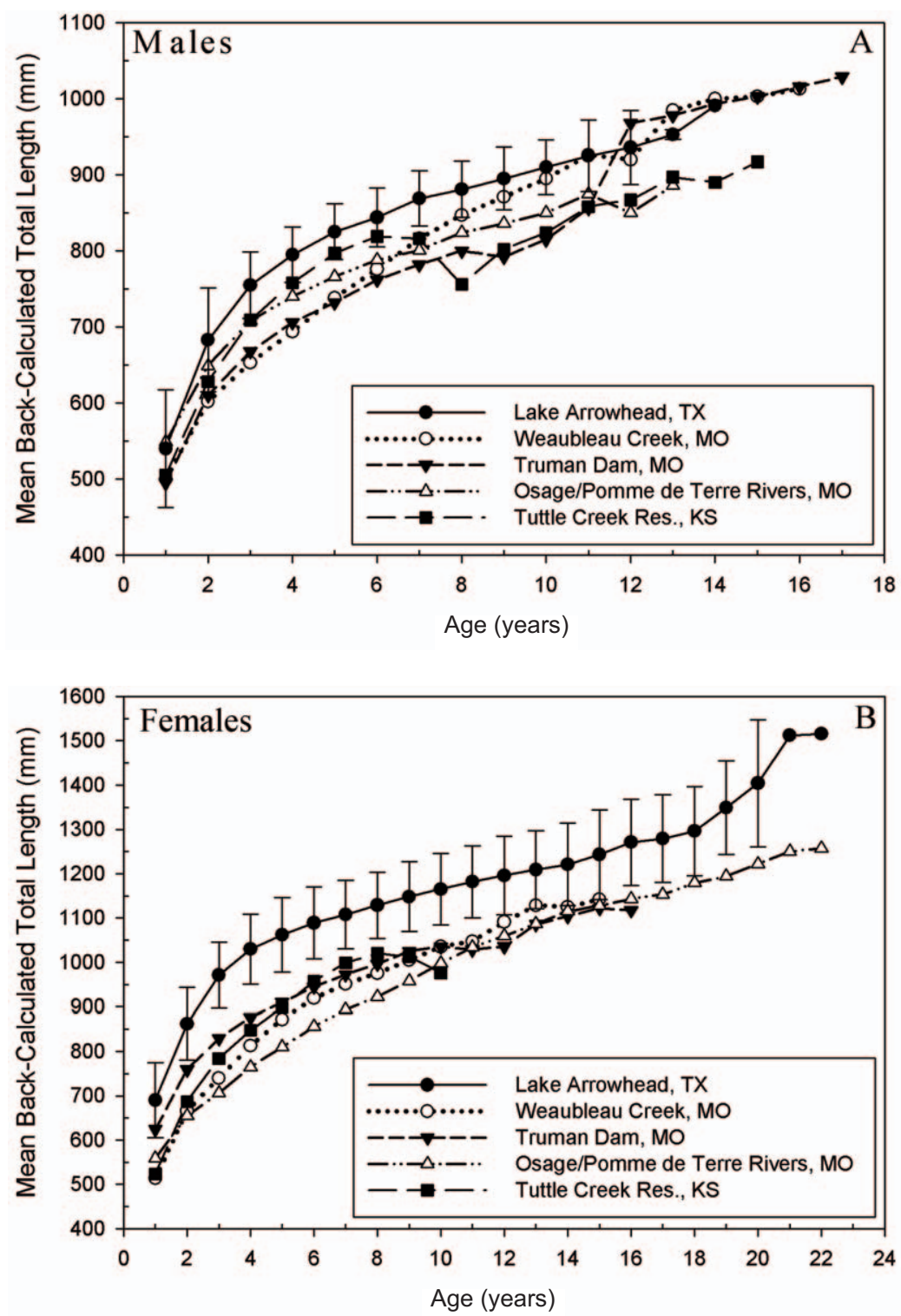

Fig. 4. Mean $( \pm \mathrm{SD})$ back-calculated total length by age comparison plots based on branchiostegal ray annuli counts for spawning longnose gar (Lepisosteus osseus) from Lake Arrowhead (filled circles, solid lines), Clay County, Texas, April-May 2010: A, males $(n=13)$, annuli counts $(n=117)$; B, females $(n=11)$, annuli counts $(n=178)$. Data points from Lake Arrowhead lacking \pm SD error bars indicate singular specimens at those age classes. Comparative means are derived from Netsch and Witt (1962; open triangles, dash-dot-dot line), Klaassen and Morgan (1974; filled squares, long-dash line), and Johnson and Noltie (1997; open circles, dotted line; inverted filled triangles, short-dash line). Means from Johnson and Noltie (1997) are derived from graphical estimates with an estimated projection error of $\pm 10 \mathrm{~mm}$.

Arrowhead grew faster and had smaller maximum lengths and shorter life spans than did females (Fig. 3B).

Comparisons of VB growth curves for longnose gar in this study to those of Sutton et al. (2009) reveal dissimilarities, but whether those differences are due to disparate latitudes, habitat (riverine vs. lacustrine system), sex ratios, or methodology is unclear. Longnose gar are sexually dimorphic (Netsch and Witt 1962, Tyler et al. 1994, Johnson and Noltie 1997, McGrath 2010), and previous studies have also indicated 
a male-biased sex ratio in longnose gar (Tyler et al. 1994, Johnson and Noltie 1996, 1997, Ferrara 2001, McGrath 2010; but see Klaassen and Morgan 1974); however, Sutton et al. (2009) did not sex captured longnose gar but generated a single growth curve for both sexes combined using a VB model of mean TL to age at capture. Their combined sex growth curve for riverine longnose gar from Indiana and Illinois yield parameter estimates $\left(L_{\infty}=1009, K=0.21, t_{0}=\right.$ $-1.62)$ that lie between those of males and females in this study (Fig. 3B).

Comparisons of VB growth curves for longnose gar in this study are similar to those of McGrath (2010) (females: $L_{\infty}=1132, K=0.18$, $t_{0}=-1.55$; males: $L_{\infty}=875, K=0.23, t_{0}=$ $-2.11)$. Like males in McGrath (2010), males in this study had greater growth-rate parameter values than females, suggesting more rapid male growth. The male growth-rate parameter value from this study exceeded that of male riverine gar in Virginia, yet female growth parameters were equal. However, asymptotic lengths of male and female longnose gar from Virginia were smaller than those presented herein (Fig. 3B).

Ferrara (2001) reported a VB growth curve for riverine female gar in Alabama with $L_{\infty}$ (1306) and $K(0.17)$ values similar to those I obtained (Fig. 3B). These similarities may be due to similar growing season lengths and higher mean temperatures. These conditions likely allow for longer, more efficient foraging periods. Moreover, Ferrara (2001) collected gar immediately below a dam in a tailrace that supported an abundance of shad (Dorosoma spp.), which may have contributed to greater growth potential.

Lake Arrowhead has an abundance of gizzard shad (Dorosoma cepedianum), with Howell and Mauk (2008) reporting catch rates of 576 per hour. Moreover, collected gizzard shad displayed a high index (88.5\%) of vulnerability (DiCenzo et al. 1996) based on catch sizes $\leq 203 \mathrm{~mm}$. Klaassen and Morgan (1974) suggested that longnose gar may grow faster and larger in reservoirs than in riverine systems because of increased abundance of gizzard shad prey. Results of this study seem to support this idea, and prey abundance may be a factor contributing to the large sizes reported herein. Such generalizations may be skewed, however, because personal observations and previous research indicate that riverine gar migrate upstream (Johnson and Noltie 1996), often congregating in dam tailraces to gorge on forage fish that congregate in the highly oxygenated waters. If prey abundance is a primary driving factor of growth potential, then riverine gar proximal to dam structures may have the capacity to match growth of reservoir gar, as illustrated by the longstanding (1954) world record longnose gar $(22.82 \mathrm{~kg}, 1842 \mathrm{~mm})$ from the Trinity River in Houston County, Texas (Meyer 2008).

This study contributes to the biological knowledge of the longnose gar and may assist conservationists and aquaculturists by providing pertinent growth and age data from a southern lacustrine system. Whereas fisheries managers once embraced eradication of gar species from public and private waters, future initiatives may reverse these policies and perhaps support stocking efforts of longnose gar as an apex predator in select lacustrine waters. There is also a growing body of research on the use of lepisosteids, including longnose gar, as aquaculture candidates for food and fisheries restocking (e.g., Alfaro et al. 2008, Jaroszewska et al. 2010). Although some results of this study corroborate previous research, much of the data herein are unique. Specifically, this report provides the first published record of (1) a scientific collection of longnose gar acquired solely using bowfishing methods, (2) sexually dimorphic VB growth curves for spawning longnose gar based on BCTLs, and (3) logtransformed regression and VB growth curves for longnose gar from any reservoir system.

\section{ACKNOWLEDGMENTS}

I thank Allyse Ferrara for freely providing both raw data and results from her Ph.D. research regarding longnose gar in Alabama for comparison to this study. Gary Burke and an anonymous reviewer provided helpful comments on earlier drafts of the manuscript.

\section{Literature Cited}

Alfaro, R.M., C.A. González, and A.M. Ferrara. 2008. Gar biology and culture: status and prospects. Aquaculture Research 39:748-763.

Burger, J., E.F. Orlando, M. Gochfeld, G.A. BincziK, AND L.J. Guillette JR. 2004. Metal levels in tissues of Florida gar (Lepisosteus platyrhincus) from Lake Okeechobee. Environmental Monitoring and Assessment 90:187-201.

BuRR, J.G. 1931. Electricity as a means of garfish and carp control. Transactions of the American Fisheries Society 61:174-182. 
DiCenzo, V.J., M.J. Maceina, and M.R. Stimert. 1996. Relations between reservoir trophic state and gizzard shad population characteristics in Alabama reservoirs. North American Journal of Fisheries Management 16:888-895.

Echelle, A.A., AND C.D. Riggs. 1972. Aspects of the early life history of gars (Lepisosteus) in Lake Texoma. Transactions of the American Fisheries Society 101: 106-112.

Ferrara, A.M. 2001. Life-history strategy of Lepisosteidae: implications for the conservation and management of alligator gar. Doctoral dissertation, Auburn University, Auburn, AL.

FERRARA, A.M., AND E.R. IRWIN. 2001. A standardized procedure for internal sex identification in Lepisosteidae. North American Journal of Fisheries Management 21:956-961

Hartley, W.R., A. Thiyagarajah, and A.M. Treinies. 1996. Liver lesions in the gar fish (Lepisosteidae) as biomarkers of exposure. Marine Environmental Research 42:217-221.

Howell, M., AND R. Mauk. 2004. Statewide freshwater fisheries monitoring and management program survey report for Arrowhead Reservoir, 2003. Texas Parks and Wildlife Department, Federal Aid Report F-30R-29, Austin, TX.

2008. Statewide freshwater fisheries monitoring and management program survey report for Arrowhead Reservoir, 2007. Texas Parks and Wildlife Department, Federal Aid Report F-30-R-33, Austin, TX.

Huang, T.L., P.O. Obih, R. Jaiswal, W.R. Hartley, and A. Thiyagarajah. 1997. Evaluation of liver and brain esterases in the spotted gar fish (Lepisosteus oculatus) as biomarkers of effect in the lower Mississippi River basin. Bulletin of Environmental Contamination and Toxicology 58:688-695.

Huggett, D.B., J.A. Steevens, J.C. Allgood, C.B. Lutken, C.A. Grace, and W.H. Benson. 2001. Mercury in sediment and fish from north Mississippi lakes. Chemosphere 42:923-929.

Jaroszewska, M., K. Dabrowski, and G. Rodriguez. 2010. Development of testis and digestive tract in longnose gar (Lepisosteus osseus) at the onset of exogenous feeding of larvae and in juveniles. Aquaculture Research 41:1486-1497.

Johnson, B.L., AND D.B. NolTiE. 1996. Migratory dynamics of stream-spawning longnose gar (Lepisosteus osseus). Ecology of Freshwater Fish 5:97-107.

1997. Demography, growth, and reproductive allocation in stream spawning longnose gar. Transactions of the American Fisheries Society 126:438-466.
Klaassen, H.E., and K.L. Morgan. 1974. Age and growth of longnose gar in Tuttle Creek Reservoir, Kansas. Transactions of the American Fisheries Society 103: 402-405.

Love, J.W. 2004. Age, growth, and reproduction of spotted gar (Lepisosteus oculatus), from the Lake Pontchartrain estuary, Louisiana. Southwestern Naturalist 49: 18-23.

McGrath, P.E. 2010. The life history of longnose gar, Lepisosteus osseus, an apex predator in the tidal waters of Virginia. Doctoral dissertation, College of William and Mary, Williamsburg, VA.

MEYER, W.P. 2008. Gar hunter, writer, stockbroker-Townsend Miller's 1954 longnose gar record still stands today [online]. [Cited 9 February 2011]. Texas Parks and Wildlife Magazine: November. Available from: http:// www.tpwmagazine.com/archive/2008/nov/legend/.

Netsch, N.F., AND A. WitT JR. 1962. Contributions to the life history of the longnose gar, (Lepisosteus osseus) in Missouri. Transactions of the American Fisheries Society 91:251-262.

QuinN, J.W. 2010. A survey of bowfishing tournaments in Arkansas. North American Journal of Fisheries Management 30:1376-1384.

Robertson, C.R., S.C. Zeug, and K.O. Winemiller. 2008. Associations between hydrological connectivity and resource partitioning among sympatric gar species (Lepisosteidae) in a Texas river and associated oxbows. Ecology of Freshwater Fish 17:119-129.

Sutton, T.M., A.C. Grier, and L.D. Frankland. 2009. Stock structure and dynamics of longnose gar and shortnose gar in the Wabash River, Indiana-Illinois. Journal of Freshwater Ecology 24:657-666.

Tyler, J.D., J.R. Webb, T.R. Wright, J.D. Hargett, K.J. Mask, AND D.R. Schucker. 1994. Food habits, sex ratios, and size of longnose gar in southwestern Oklahoma. Proceedings of the Oklahoma Academy of Science 74:41-42.

VON BERTALANFFY, L. 1938. A quantitative theory of organic growth. Human Biology 10:181-213.

Watanabe, K.H., F.W. Desimone, A. Thiyagarajah, W.R. HaRtLey, and A.E. HindRICHS. 2003. Fish tissue quality in the lower Mississippi River and health risks from fish consumption. Science of the Total Environment 302:109-126.

Received 9 June 2011 Accepted 11 October 2011 